\title{
PENGEMBANGAN KEMAMPUAN MEMBACA PERMULAAN MELALUI METODE FONIK PADA TAMAN KANAK-KANAK BHAYANGKARI
}

\author{
Haryati \\ Dosen PG-PAUD FKIP Universitas Khairun
}

On of the important competences and must be masteredby children are reading and writing. Because reading and writing competence supporting in some aspects of children language. From those competence starting introduce in pre school so they can progress in the future. Attention in phonic cah help children to progress strategies in understanding some words that rarely meet in daily activity. Context used for help children understand the meaning and the sounds and its sentences.

\section{PENDAHULUAN}

Anak-anak adalah generasi penerus bangsa.Oleh karena itu mereka harus disiapkan sejak dini agar mempunyai kemampuan, karakter dan kepedulian terhadap perkembangan bangsa dan negaranya, dan pembentukan kemampuan, karakter dan kepedulian terhadap perkembangan bangsa dan negara itu dilakukan melalui pendidikan baik pendidikan formal, non formal maupun informal. Salah satu kemampuan yang penting dan harus dikuasai oleh anak-anak adalah kemampuan membaca dan menulis.Karena kemapuan membaca dan menulis sangat menunjang pada aspek-aspek perkembangan lainnya terutama pada aspek perkembangan bahasa anak. Maka dari itu kemampuan ini dapat mulai diasah atau di kenalkan sejak usia pra sekolah sehingga anak tidak mengalami kesulitan pada jenjang berikutnya.

Namun, cara yang dapat digunakan dalam belajar membaca dan menulis itu memiliki berbagai macam cara yang dapat meningkatkan minat dan kemampuan anak dalam belajar membaca, salah satunya adalahSalah satu cara yaitu dengan menggunakan kartu kata (flash card) dengan cara mengajarkan fonik pada anak. Dengan penggunaan kartu kata anak dapat belajar membaca permulaan dengan bermain karena kartu kata disertai dengan gambar yang berwarna, sehingga anak-anak merasa sedang bermain walaupun sebenarnya meraka sedang belajar. Anak diajarkan bunyi perhuruf dengan kata yang ada di kartu kata. Pengajaran Membaca Permulaan seseorang anak sangat ditentukan oleh kemampuannya saat belajar membaca permulaan. Pelajaran membaca permulaan mengajarkan pengenalan huruf dan rangkaiannya, seperti: suku kata, kata, dan kalimat sederhana.

Berdasarkan survey awal, kemampuan membaca permulaan anak di Taman Kanak-kanak Bhayangkari tergolong masih kurang, ini dapat dilihat dari keadaan, anak belum mampu mengenali huruf dan melafazkan bunyi huruf secara sederhana. Sebagai contoh anak masih sulit membedakan antara huruf $b$ dan $p$ atau huruf $m$ dan $n$. Usaha 
untuk mengembangkan kemampuan membaca ini juga dilakukan para pendidik Taman Kanak-kanak setiap harinya. Sebagai contoh, pendidik seringkali mengajak anak untuk bermain dengan memperlihatkan kartu kata dengan berbagai variasi gambar sesuai tema yang diajarkan. Dari fenomena di atas, maka penulis terdorong untuk mengkaji secara empirik mengenai Pengembangan Kemampuan Membaca Permulaan Melalui Metode Fonik Di Taman Kanak-Kanak Bhayangkari.

\section{KAJIAN PUSTAKA}

\section{Pengertian Membaca Permulaan}

Menurut Kamus Besar Bahasa Indonesia (1999: 623), "kemampuan" berarti kesanggupan atau kecakapan. "Membaca" berarti melihat serta memahami isi dari apa yang tertulis, atau mengeja dan melafalkan apa yang tertulis (KBBI, 1999: 72). Petty dan Jensen (Ampuni, 1998: 16) menyebutkan bahwa "definisi membaca memliki beberapa prinsip, di antaranya membaca merupakan interpretasi simbol-simbol yang berupa tulisan, dan bahwa membaca adalah mentransfer ide yang disampaikan oleh penulis bacaan". Maka dengan kata lain membaca merupakan aktivitas sejumlah kerja kognitif termasuk persepsi dan rekognisi. Terdapat beberapa tahap dalam proses belajar membaca. Menurut Mercer (Abdurrahman, 2002: 201) bahwa "membaca permulaan(Initial reading) merupakan tahap kedua dalam membaca". Chall (Ayriza, 1995: 20) "Tahap ini ditandai dengan penguasaan kode alfabetik, di mana anak hanya sebatas membaca huruf per huruf atau membaca secara teknis".

Menurut Mar'at (2005: 80) bahwa "membaca secara teknis juga mengandung makna bahwa dalam tahap ini anak belajar mengenal fonem dan menggabungkan (blending) fonem menjadi suku kata atau kata". Kemampuan membaca ini berbeda dengan kemampuan membaca secara formal membaca pemahaman, dimana seseorang telah memahami makna suatu bacaan. Tidak ada rentang usia yang mendasari pembagian tahapan dalam proses membaca, karena hal ini tergantung pada tugas-tugas yang harus dikuasai pembaca pada tahapan tertentu. Karena "kemampuan membaca dan menulis merupakan bekal utama bagi anak-anak untuk dapat memahami mata pelajaran yang diberikan di sekolah". (Stephens, 2004:34)

Berdasarkan uraian di atas, dapat disimpulkan bahwa pengertian kemampuan membaca permulaan me 4 pada kecakapan (ability) yang harus dikuasai pembaca yang berada dale ${ }^{4}$ ahap membaca permulaan. Kecakapan yang dimaksud adalah penguasan kode alfabetik, di mana pembaca hanya sebatas membaca huruf per huruf, mengenal fonem, dan menggabungkan fonem menjadi suku kata atau kata.

Membaca permulaan ialah membaca yang diajarkan secara terprogram (secara formal) kepada anak pra sekolah.Dimana pengajaran membaca secara umum dapat dibagi kedalam dua tahap yaitu pengajaran membaca permulaan dan pengajaran membaca lanjutan. 
Adapun menurut Darwadi (2002) menyatakan bahwa membaca permulaan merupakan tahap awal dalam belajar membaca yang difokuskan kepada mengenal symbol-simbol atau tanda-tanda yang berkaitan dengan huruf-huruf sehingga menjadi pondasi agar anak dapat melanjutkan ketahap membaca permulaan. Sedangkan tahapmembacalanjutan menurut Amin, (1995: 211) "Membaca lanjutan adalah anak tidak sekedar mengenal symbol atau tanda-tanda tapi sudah mempergunakannya untuk membaca kata atau kalimat sehinnga anak memahami ape yang di bacanya."

Membaca permulaan merupakan saat kritis dan strategis di kembangkannya kemampuan membaca tanpa teks yaitu membaca dengan cara menceritakan gambar situasional yang tersedia. Pengembangan yang tepat pada membaca permulaan ini perlu sekali, biasanya yang paling cocok dan sesuai alarn anak yaitu membaca sambil bermain misalnya membaca menggunakan permainan kartu kata bergambar. Menurut Shodiq (1996: 126) menyatakan bahwa "Membaca permulaan merupakan tahap membaca permulaan yang lebih diarahkan kepada membaca".Pada tahap membaca permulaan anak membaca huruf atau kata tidak lagi terlalu tergantung pada lingkungan tetapi pada saat tiba masa peka anak yaitu anak usia 6 tahun atau 7 tahun bagi anak normal". Pada tahap membaca ini kemandirian anak pada saat membaca mulai ada tetapi anak belum bisa di lepas sepenuhnya saat membaca kata atau kalimat untuk itu tahap ini masih perlu ada bantuan yang diberikan oleh guru atau orang tua kepada anak melalui berbagai latihan terbimbing.

Dengan demikian penulis dapat menyimpulkan bahwa membaca permulaan merupakan tahap awal anak belajar membaca dengan focus ada pengenalan simbolsimbol huruf dan aspek-aspek yang mendukung pada kegiatan membaca lanjutan. Oleh karena itu pengajaran remedial pada membaca permulaan memiliki peranan penting untuk mengatasi kesulitan-kesulitan membaca yang dihadapi oleh anak.karena "Anak-anak cenderung lebih suka bermain dengan warna, gambar, suara, lagu dan mendengarkan cerita daripada belajar dengan cara tradisional"(Izhar, 1998:45).

Purwanto dan Alim (1997:3) "pelajaran membaca permulaan bertujuan untuk memberikan kemampuan mengenal huruf dan mengubahnya menjadi rangkaian bunyi yang bermakna serta melancarkan teknik membaca pada anak-anak". Pelajaran membaca permulaan biasanya dimulai tanpa menggunakan buku pelajaran karena mereka belum dapat membaca.Walaupun pelajaran membaca permulaan tidak di mulai dengan menggunakan buku tetapi tetap menggunakan tulisan.Ada beberapa alasan mengapa pelajaran membaca permulaan menggunakan tulisan Burns, Roe, dan Ross (1984).Alasan pertama adalah pengenalan tulisan sejak awal dapat membuat anak memiliki pengalaman membaca yang baik dan memberikan pengaruh sikap yang baik dalam membaca.Kedua, anak dapat mulai menyadari bahwa tulisan merupakan rekaman bunyi yang teratur.Alasan ketiga, bagi pembaca pemula, kata-kata lebih mempunyai arti daripada dihafalkan. Hal ini berakibat, dengan mengajarkan kata sejak awal akan lebih mudah di ingat oleh anak daripada menghafalkan huruf-huruf yang menyusun kata tersebut. Selain dari ketiga alasan di atas ada beberapa alasan lain yaitu dengan menggunakan tulisan anak akan mempunyai tambahan pengetahuan 
bahwa membaca tulisan dan menulis dalam bahasa Indonesia itu harus dilakukan dari kiri ke kanan, dari atas ke bawah, mengenal kata-kata yang sering digunakan dan pengalaman-pengalaman baru lainnya yang tanpa disadari oleh si anak dan tanpa dipaksakan sudah terekam di otaknya.

\section{Manfaat Membaca Permulaan}

Steinberg (1982: 214-215) mengemukakan bahwa setidaknya ada empat manfaat mengajar anak membaca permulaan (dini) dilihat dari segi proses belaiar mengajar adalah sebagai berikut:

(a) Belajar membaca permulaan (dini) memenuhi rasa ingin tabu anak; (b) Situasi akrab dan informal di nimah dan di TK atau KBmerupakan faktor yang kondusif bagi anak untuk belajar; (c). Anak-anak yang berusia dini pada umumnya perasa dan mudah terkesan, serfs dapat di atur; (d). Anak-anak yang berusia dini dapat mempelajari sesuatu dengan mudah dan cepat.

\section{Prinsip-prinsip Pokok Membaca Permulaan}

Bertitik tolak dari pengertian bahwa membaca adalah kegiatan fisik dan mental untuk menemukan makna dari tulisan, dan membaca perintilaan. (dini) adalah merupakan usaha mempersiapkan anak memasuki pendidikan dasar, maka penulis berpendapat bahwa kelima prinsip pokok membaca permulaan (dini) yang dikemukakan oleh Steinberg adalah sebagai berikut :

Prinsip pertama ialah bahwa materi bacaan harus terdiri atas kata-kata, frasefrase, dan kalimat-kalimat.Ini berarti bahwa bahan bacaaan itu harus mempunyai makna yang dapat dipahami oleh anak.Selanjutnya ini juga berarti bahwa bahan-bahan pelajaran itu harus berhubungan erat dengan pengalaman anak.Selanjutnya ini juga berarti bahwa bahan-bahan pelajaran itu harus berhubungan erat dengan pengalaman anak, atau frase yang pernah dialami. Dengan demikian kata-kata,frase-frasedan kalimat-kalimat itu sedapat-dapatnya hendaknya berasal dari pembendaharaan kata anak itu. Prinsip kedua adalah bahwa membaca terutama didasarkan pada kemampuan memahami bahasa lisan dan bukan pada kemampuan berbicara.Prinsip ini sesuai dengan dasar pembagian keempat keterampilan berbahasa yaitu mendengarkan (menyimak) dan membaca adalah termasuk pemahaman bahasa, sedangkan berbicara dan menulis termasuk pemproduksian bahasa.Jadi membaca adalah salah satu keterampilan memahami bahasa dan dengan demikian sejalan dengan mendengarkan.

Prinsip ketiga ialah bahwa mengajar bukan mengajarkan aspek-aspek kebahasan seperti tata bahasa, kosa kata dan lain-lain, dan bukan mengajarkan logika atau cara berpikir. Ini berarti bahwa pengertian membaca yang dikemukakan pada permulaan bagian ini harus dipegang yaitu bahwa membaca adalah menemukan makna dari tulisan. Oleh karena itu, bahan-bahan pelajaran membaca permulaan (dini) haruslah yang berada dalam ruang lingkup kemampuan bahasa dan berpikir anak. Prinsip keempat ialah bahwa membaca tidak harus bergantung pada pengajaran 
menulis.Ini berarti bahwa anak dapat membaca, walaupun dia belum dapat menulis.Sebagai berikut diatas, menulis adalah termasuk keterampilan memproduksi bahasa, jadi tak harus menjadi dasar untuk belajar membaca walaupun keduanya berhubungan erat. Membaca seharusnya lebih dahulu, karena kalau membaca telah dikuasai, keterampilan menulis akan lebih mudah dipelajari, sebab persepsi tentang bentuk huruf-huruf telah ada dlam pikiran anak.

Prinsip kelima ialah bahwa pengajaran membaca harus menyenangkan bagi anak.Ini sesuai dengan sifat perkembangan anak dimana dia suka bermain dan lekas merasa bosan.Oleh sebab itu pelajaran membaca permulaan (dini) harus dibuat menarik, diusahakan dalam situasi bermain dan tidak terlalu lama.

Dengan demikian prinsip diatas, program yang disusun olteinberg terdiri dari empat fase, yaitu sebagai berikut:

a. Fase pembiasaan kata

Fase ini bertujuan untuk membiasakan anak dengan bentuk kata-kata tertulis dan menimbulkan serta menggembangkan kesadarannya akan perbedaan kata-kata tertulis.

b. Fase pengenalan kata

Fase ini bertujuan untuk mengajarkan anak-anak agar dia mengetahui kata tertulis mana yang dihubungkan dengan (yang menjadi lambang dari) kata yang diucapkan dan objek yang diacunya.

c. Fase pengenalan frase dan kalimat

Fase ini bertujuan untuk mengajarkan anak agar dia mengetahui frase dan kalimat tertulis mana, yang dihubungkan dengan frase atau kalimat yang diucapkan dan objek yang diacunya.

d. Fase pemahaman teks

Fase ini bertujuan untuk mengajar anak agar dapat membaca dan memahami bacaan (teks) yang sederhana yang terdiri atas beberapa kalimat yang sederhana.

\section{Tujuan Umum Pengajaran Membaca Permulaan}

Pengajaran membaca permulaan, menurut Soejono (Lestary, 2004, h. 12) memiliki tujuan yang memuat hal-hal yang harus dikuasai siswa secara umum, yaitu:

a) Mengenalkan siswa pada huruf-huruf dalam abjad sebagai tanda suara atau tanda bunyi,

b) Melatih ketrampilan siswa untuk mengubah huruf-huruf dalam kata menjadi suara.

c) Pengetahuan huruf-huruf dalam abjad dan keterampilan menyuarakan wajib untuk dapat dipraktikkan dalam waktu singkat ketika siswa belajar membaca lanjut. 


\section{Tahapan Proses Belajar Membaca}

Grainger (Sugiono, 2003:185) menyebutkan "adanya tiga tahapan dalam proses membaca". Tahap prabaca dapat dilihat dari kesiapan anak untuk memulai pengajaran formal dan tergantung pada kesadaran fonemis anak. Anak yang dinyatakan siap (biasanya pada anak-anak yang baru memasuki usia prasekolah) kemudian akan melalui tahap pertama dalam proses membaca. Tahap pertama adalah tahap logografis, anak-anak taman kanak-kanak atau awal kelas 1 menebak kata-kata berdasarkan satu atau sekelompok kecil huruf sehingga tingkat diskriminasi sangat buruk. Kemudian setelah mendapat pengajaran, diskriminasi menjadi lebih baik".Anak dapat membedakan kata yang sudah dan belum dikenal, namun mereka belum dapat membaca kata-kata yang belum dikenal. Strategi membaca awal pada tahap logografis secara umum tidak bersifat fonologis, tetapi lebih bersifat pendekatan global atau visual di mana pembaca awal mencoba mengidentifikasi kata secara keseluruhan berdasarkan cirri-ciri yang bisa dikenali. Tahap kedua adalah tahap alfabetis, pada tahap ini pembaca awal memperoleh lebih banyak pengetahuan tentang bagaimana membagi kata-kata ke dalam fonem-fonem dan bagaimana merepresentasikan bunyi-bunyi yang mereka baca dan eja dengan ortografi alfabet.

Tahap ketiga dilalui ketika anak sudah lancar dalam proses dekoding. Anak pada tahap ini mampu memecahkan kata-kata yang beraturan dan tak beraturan dengan menggunakan konteks. Biasanya tahap ini berlangsung ketika anak berada pada pertengahan sampai akhir kelas 3 dan kelas 4 sekolah dasar. Anak akan lebih mudah dan senang belajar jika suatu pembelajaran dilakukan dengan cara-cara yang menyenangkan. Ketika anak senang maka otak memberikan respon untuk siap menyerap informasi apapun yang di perolehnya.Hal ini di sebabkan kondisi limbic sebagai pusat emosi otak yang memunculkan rasa senang membuka korteks sebagai otak berpikir anak.Rasa senang ini di timbulkan oleh adanya hormone endorphin yang di hasilkan melalui kegiatan fisik, olahraga dan permainan-permainan. Untuk itu sangat tepatlah mengajarkan membaca dengan cara bermain melalui mainan dan permainan yang memiliki konsep dan tujuan yang jelas. Jika membaca di ajarkan dengan cara-cara konvensional, dimana anak hanya di hadapkan pada buku dan pensil, anak akan merasa bahwa kegiatan membaca merupakan sesuatu yang tidak menyenangkan. Padahal kita tahu, bahwa minat baca harus di tumbuhkan sejak awal.Bagaimana mungkin minat itu muncul dalam diri anak jika suasana yang di ciptakan tidak merangsang minat anak.

Indikator Membaca Permulaan Pada Peraturan Menteri Pendidikan Nasional Nomor 58 Tahun 2009 Tanggal 17 September 2009, indikator keaksaraan tahap usia 4 sampai $\leq 6$ tahun, terdiri atas kelompok usia sebagai berikut :

1) Usia 4 sampai $<5$ tahun
a. Mengenal simbol-simbol.
b. Mengenal suara-suara hewan/benda yang ada di sekitarnya.
c. Membuat coretan yang bermakna. 


\section{d. Meniru huruf}

2) Usia 5 sampai $\leq 6$ tahun

a. Menyebutkan simbol-simbol huruf yang dikenal.

b. Mengenal suara huruf awal dari nama benda-benda yang ada di sekitarnya.

c. Menyebutkan kelompok gambar yang memiliki bunyi atau huruf awal yang sama.

d. Memahami hubungan antara bunyi dan bentuk huruf, membaca nama sendiri.

\section{Pengertian Metode Fonik}

Menurut Thoifuri (2007: 56) metode berasal dari bahasa Greeka-Yunani yaitu metha (melalui atau melewati), dan hodos (jalan atau cara). Asal makna kata tersebut dapat diambil pengertian secara sederhana adalah jalan atau cara yang ditempuh oleh seorang guru dalam menyampaikan ilmu pengetahuan pada anak didiknya sehingga dapat mencapai tujuan. Sedangkan Ahmad (1997: 9) mendifinisikan metode dalam interaksi pembelajaran adalah "suatu cara yang tepat dan cepat melakukan sesuatu. Cara yang tepat dan cepat inilah maka urutan kerja dalam suatu metode harus diperhitungkan benar-benar secara ilmiah". Menurut Moeslichatoen (2004: 7) metode "merupakan bagian dari strategis kegiatan, metode dipilih berdasarkan strategi kegiatan yang sudah dipilih dan ditetapkan". Jadi metode adalah merupakan cara yang dalam bekerjanya merupakan alat untuk mencapai suatu tujuan. Sedangkan kata "fonik" berasal dari kata "phoneme" yang artinya unit terkecil dari bicara. Dalam kata "dan", misalnya terdapat tiga fonem: /d//a/,/dan /n/. Huruf-huruf lain dalam sebuah kata menentukan bunyi khas yang dibuat oleh sebuah huruf. Apabila berdiri sendiri huruf tidak membuat bunyi khusus. Misalnya huruf /e/ membuat bunyi berbeda dalam kata "rem" dan dalam kata "set". Bahkan bunyi-bunyi huruf mati (konsonan) berubah sesuai dengan konteks, seperti perbedaan dalam bunyi /d/ dalam "abad" dan "baghdad".

Metode fonik menekankan pada pengenalan kata melalui proses mendengarkan bunyi huruf. Pada mulanya anak diajak mengenal bunyi-bunyi huruf, kemudian mensintesiskannya menjadi suku kata dan kata.Bunyi huruf dikenalkan dengan mengaitkannya dengan kata benda, misanya huruf "a" dengan gambar "ayam" (Sessiani, 2007:33). Dengan demikian, metode ini lebih bersifat sintesis daripada analitis. Metode fonik untuk membaca menekankan pada (a) pemahaman hubungan huruf-huruf dan bunyi-bunyi didalam kata, dan (b) penerapan hubungan ini untuk menganalisis dan mengartikan kata-kata yang belum dikenal.Dalam sebuah metode fonik untuk membaca, anak-anak secara terang-terangan diajarkan bagaimana hurufhuruf abjad dan kelompok-kelompok huruf diterapkan pada bunyi-bunyi didalam kata.Ini disebut sebagai pelajaran yang menekankan kode atau berbasis kode.Falsafah yang mendasarinya adalah mengajarkan kepada anak-anak strategi-strategi untuk mengerti bagian sebuah kata berdasarkan bunyi yang ditemukan didalam kata itu.Kata-kata kelu (sight words) kata-kata yang sulit di ucapkan karena mereka tidak mengikuti aturanaturan bunyi juga diajarkan dengan menggunakan metode fonik.

Penekanan pada fonik menolong anak-anak mengembangkan strategi-strategi sehingga mereka bisa mengartikan kata-kata yang jarang mereka jumpai.Konteks dipakai untuk membantu anak-anak memahami arti kata tersebut. Mengetahui masing- 
masing bunyi di dalam kata-kata akan membantu anak-anak mengartikan kata-kata, dan memahami konteks akan membantu membawa makna kepada kata-kata dan kalimat.

Menulis dan mengucapkan adalah bagian penting dari pelajaran fonik.Menulis kata-kata untuk mengungkapkan gagasan dan sikap menuntut orang untuk fokus pada bunyi khusus dalam kata. Ejaan ciptaan atau ucapan bunyi memungkinkan para guru memahami pengetahuan anak-anak tentang bunyi-bunyi di dalam kata. Orangtua seringkali merasa cemas melihat anaknya belum bisa membaca, mereka khawatir jika anak mereka belum bisa membaca, maka anak tersebut akan mengalami kesulitan untuk tingkat selanjutnya dan sulit diterima di sebuah sekolah dasar. Walaupun sebenarnya tidak ada aturan yang mengatakan bahwa siswa sekolah dasar pada kelas satu sudah harus bisa membaca, akan tetapi pada kenyataan dilapangan, bahwa untuk memasuki sekolah dasar maka anak dituntut untuk mengikuti tes baca tulis pada penyaringan siswa baru. Berangkat dari permasalahan tersebut maka muncullah kekhawatiran tersebut dibenak para orangtua sehingga mereka mendesak para guru di lembaga pendidikan anak usia dini untuk melakukan pembelajaran yang berorientasi pada baca tulis hitung, dengan alasan sebagai suatu persiapan kesuksesan di SD nantinya. Sementara itu hal tersebut sangat bertolak belakang dengan proses pembelajaran pada pendidikan anak usia dini (PAUD) seru bisa mengenalkan proses memharusya melalui proses belajar sambil bermain atau belajar seraya bermain. Akan tetapi orang tua maupun guru bisa ngenalkan bagaimana cara membaca pada anak usia dini sesuai dengan tahap perkembangannya, akan tatapi perlu dilakukan melalui kegiatan bermain yang fungsional dan kontekstual.

Tidaklah cukup hanya menciptakan seorang anak yang bisa membaca dengan tujuan menyenangkan orang dewasa. Kita perlu mengenalkan anak pada bacaan untuk mencintai buku dan kegiatan membaca sebagai proses belajar yang menyenangkan. Nantinya pada masa dewasa anak akan merasakan manfaat yang besar atas kesenangannya dalam membaca. Membaca sebenarnya bukan proses yang sulit dan rumit jika mengetahui cara membaca dengan benar. Cobalah untuk sabar dan menunggu sesuai dengan proses kesiapan anak. Jika anak mampu mengenali bunyibunyi di sekitarnya, suatu saat dia pasti akan dapat membaca. Anak memerlukan proses yang panjang agar memiliki kesiapan untuk membaca.

Pemahaman terhadap simbol-simbol sangat mendukung anak untuk dapat membaca.Kemampuan untuk mengenali suara orangtua, wajah orang-orang di sekelilingnya, dan benda-benda yang ada di lingkungan anak merupakan suatu kemampuan untuk memaknai suatu simbol. Jika anak dapat memaknai simbol-simbol, lebih mudah baginya untuk mewakilkan bunyi-bunyi suatu huruf kedalam bentuk-bentuk alphabet. Jadi untuk memastikan bahwa anak akan dapat membaca dengan cara yang benar, persiapkanlah sedini mungkin dengan aneka bunyi-bunyian. Tentukan bukan asal bunyi. 
Pola pemikiran yang demikian dapat di lihat sebagai berikut:

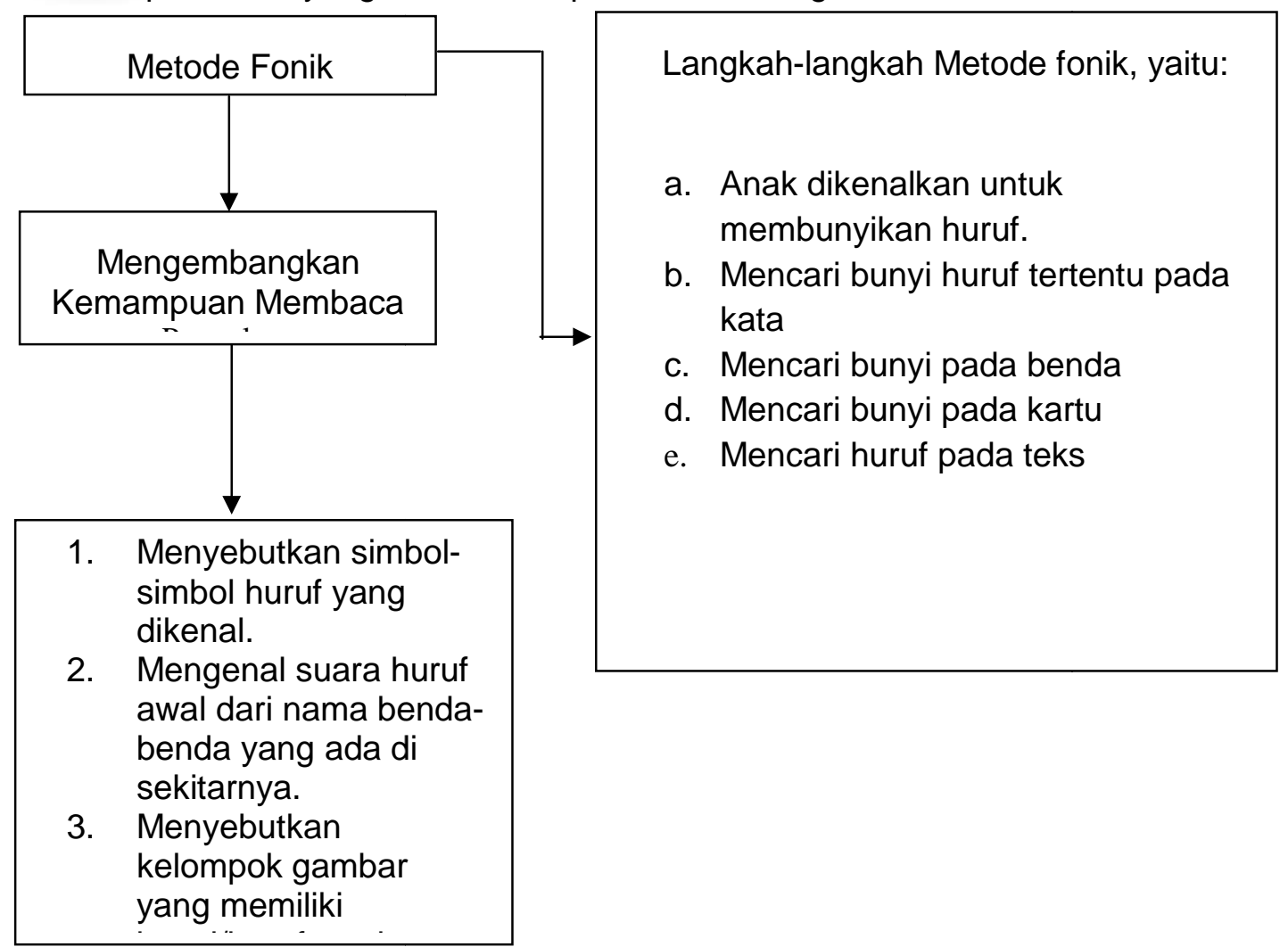

\section{Hipotesis Tindakan}

Kemampuan membaca permulaan pada anak kelompok B di Taman Kanak-kanak Bhayangkari dapat dikembangkan melalui metode fonik.

\section{METODE}

\section{Pendekatan dan Jenis Penelitian}

Penelitian ini menggunakan pendekatankualitatif deskriptif. Dan untuk jenis penelitian yang digunakan dalam penelitian ini adalah menggunakan penelitian tindakan kelas (PTK), sedangkan yang menjadi alasan dalam penelitian ini karena penelitiberupayamengembakan kemampuan membaca permulaan anak melalui metode fonik, disamping itu juga peneliti berusaha mengkaji dan merefleksikan secara mendalam antara kemampuan membaca permulaan dengan metode fonik dalam proses belajar mengajar di Taman Kanak-kanak.

\section{Fokus Penelitian}

Dalam penelitian ini yang menjadi fokus penelitian adalah kemampuan membaca permulaan anak dapat ditingkatkan melalui penggunaan metode fonik, dimana guru sebagai fasilitator dalam mengajar kemampuan membaca permulaan mengajarkan 
bunyi huruf yang kemudian sang anak didik memperhatikan sehingga terjadilah transformasi pengetahuan dari guru ke anak didik di Bhayangkari

\section{Setting dan Subjek Penelitian}

Yang menjadi sasaran dalam penelitian ini adalah seluruh anak Taman Taman Kanak-Kanak Bhayangkari yang berjumlah 52 orang. Sedangkan yang menjadi subyek penelitian adalah kelompo $B_{2}$ yang berjumlah 10 orang dan guru yang mengajar sebanyak 1 orang.

\section{Rancangan Tindakan}

Desain penelitian yang akan dilaksanakan adalah sebagai berikut:

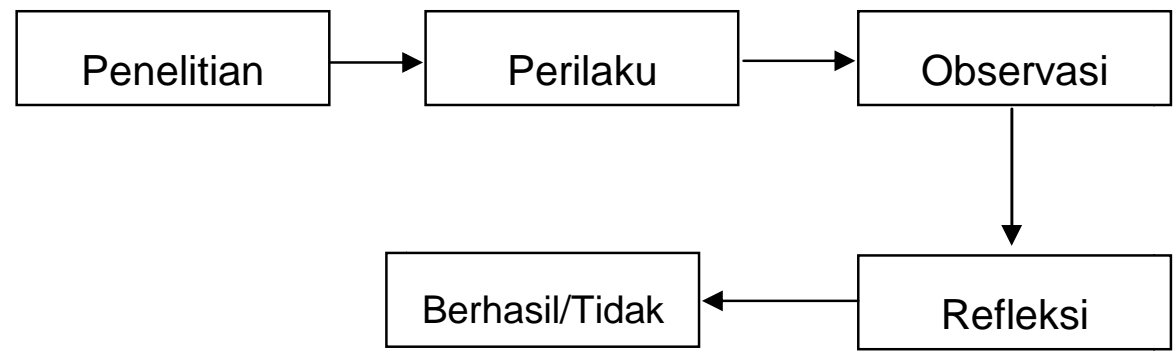

Pada pembelajaran I siklus I yang diamati adalah: 1) Anak yang mampu menyebutkan simbol-simbol huruf, 2) Anak mampu mengenal suara huruf awal dari nama benda-benda yang ada di sekitar, 3) Anak mampu menyebutkan kelompok gambar yang memiliki bunyi/huruf awal yang sama, 4) Anak mampu memahami hubungan antara bunyi dan bentuk huruf, dan 5) Anak mampu membaca nama sendiri. Gambaran hasilnya adalah sebagai berikut:

Tabel 3: Hasil Evaluasi Pembelajaran I siklus I

\begin{tabular}{|l|c|c|c|}
\hline \multirow{2}{*}{ Nama Anak } & \multicolumn{3}{|c|}{ No. Item Hal-hal Yang Diamati } \\
\cline { 2 - 4 } Ahmad Rian & Sangat Mampu & Mampu & Belum Mampu \\
\hline Ahmad Nursyam & - & - & $1,2,3,4,5$ \\
\hline Dzul Khaerat & - & - & $1,2,3,4,5$ \\
\hline Hafidz Arham & - & 2,5 & 3,4, \\
\hline Inar Ramadani & - & $1,2,5$ & 3,4 \\
\hline Muh. Rifaldi & - & - & $1,2,4,5$ \\
\hline Nur Fadilla & - & - & $1,2,3,4,5$ \\
\hline Nurul Azkiyah & - & $1,2,4$ & $1,2,3,4,5$ \\
\hline Sajidatulfa & - & 3 & 3,5 \\
\hline
\end{tabular}




\begin{tabular}{|ll|l|l|l|}
\hline $\begin{array}{l}\text { Wahyu } \\
\text { Wardani }\end{array}$ & Ika & - & 2 & $1,3,4,5$ \\
\hline
\end{tabular}

Dari evaluasi pada tabel di atas menunjukkan kemampuan membaca permulaan anak kelompok B di Taman Kanak-kanak Aisiyah Bustanul Athfal pada pembelajaran I.

Hasil Evaluasi Pembelejaran II siklus II

\begin{tabular}{|l|c|c|c|}
\hline \multirow{2}{*}{ Nama Anak } & \multicolumn{3}{c|}{ No. Item Hal-hal Yang Diamati } \\
\cline { 2 - 4 } Ahmad Rian & Sangat Mampu & Mampu & Belum Mampu \\
\hline Ahmad Nursyam & 1,3 & $2,4,5$ & - \\
\hline Dzul Khaerat & $1,2,4$ & 1,5 & 4 \\
\hline Hafidz Arham & $1,4,5$ & 3,5 & 3 \\
\hline Inar Ramadani & 2 & 2 & 4 \\
\hline Muh. Rifaldi & 3 & $2,3,5$ & 1 \\
\hline Nur Fadilla & 5 & $1,2,4$ & 3 \\
\hline Nurul Azkiyah & $1,2,5$ & 3,4 & - \\
\hline Sajidatulfa & 2,4 & 1,3 & 5 \\
\hline Wahyu Ika Wardani & 3,5 & 2,4 & 1 \\
\hline
\end{tabular}

Dari evaluasi pada tabel di atas menunjukkan kemampuan membaca permulaan anak kelompok B di Taman Kanak-kanak. Hasil penelitian tersebut di atas menunjukkan bahwa dari 5 item yang diamati pada umumnya sudah masuk kategori baik karena anak-anak kemampuan membaca permulaannya sudah ada yang masuk pada penilaian sangat mampu dan mampu, meskipun masih ada sebagian kecil anak yang kemampuan mambacanya belum mampu. Hal tersebut menunjukkan bahwa kemampuan membaca permulaan anak, semakin meningkat setelah diberikan perlakuan berupa metode fonik.

\section{KESIMPULAN}

\section{Kesimpulan}

Berdasarkan hasil penelitian dan pembahasan di atas, maka dapat disimpulkan bahwa metode fonik dapat mengembangkan atau meningkatkan kemampuan membaca permulaan anak pada Kelompok B di Taman Kanak-kanak Aisyiyah Bustanul Athfal. 